\title{
Autosomal Dominant Polycystic Disease is Associated with Depressed Levels of Soluble Tumor Necrosis Factor-Related Apoptosis-Inducing Ligand
}

\author{
Funda Sarı ${ }^{1}$, Arzu Didem Yalçın², Gizem Esra Genç ${ }^{3}$, Metin Sarıkaya ${ }^{1}$, Atıl Bisgin ${ }^{4}$, Ramazan Çetinkaya ${ }^{1}$, \\ Saadet Gümüşlü ${ }^{3}$
}

\author{
${ }^{1}$ Division of Nephrology, Department of Internal Medicine, Antalya Training and Research Hospital, Antalya, Turkey \\ ${ }^{2}$ Department of Internal Medicine, Antalya Training and Research Hospital, Antalya, Turkey \\ ${ }^{3}$ Department of Biochemistry, Akdeniz University School of Medicine, Antalya, Turkey \\ ${ }^{4}$ Department of Clinical and Experimental Medicine, University of Linköping School of Health Sciences, Linköping, Sweden
}

Background: Autosomal dominant polycystic kidney disease (ADPKD) is characterized by multiple, large renal cysts and impaired kidney function. Although the reason for the development of kidney cysts is unknown, ADPKD is associated with cell cycle arrest and abundant apoptosis of renal tubular epithelial cells.

Aims: We asked whether serum-soluble TNF-related apoptosis-inducing ligand (sTRAIL) might underlie ADPKD.

Study Design: Case-control study.

Methods: Serum sTRAIL levels were measured in 44 patients with ADPKD and 18 healthy volunteers.

The human soluble TRAIL/Apo2L ELISA kit was used for the in vitro quantitative determination of sTRAIL in serum samples.
Results: Mean serum sTRAIL levels were lower in patients with ADPKD as compared to the control group $(446.9 \pm 103.1$ and $875.9 \pm 349.6 \mathrm{pg} / \mathrm{mL}$, $\mathrm{p}<0.001)$. Serum sTRAIL levels did not differ among stages of renal failure in patients with ADPKD. There was no correlation between serum sTRAIL levels and estimated glomerular filtration rate in patients with ADPKD ( $>>0.05)$.

Conclusion: Our results show that ADPKD patients have depressed sTRAIL levels, indicating apoptosis unrelated to the stage of chronic renal failure.

Keywords: Serum-soluble TNF-related apoptosisinducing ligand, chronic kidney disease, autosomal dominant polycystic kidney disease
Autosomal dominant polycystic kidney disease (ADPKD) is a disorder characterized by multiple, large renal cysts and impaired kidney function. Although the mechanism involved in the pathogenesis of ADPKD is unknown, it is thought to involve cellular proliferation, ending in the development of multiple and big cysts, modified renal epithelial cell polarity, dislocation of $\mathrm{Na}+-\mathrm{K}+$ ATPase pump and remodeling of the matrix $(1,2)$. The precise mechanism implicated in the patho- genesis of ADPKD has not been identified. Apoptosis is a pathologic feature of ADPKD (3-5).

TNF-related apoptosis-inducing ligand (TRAIL) derives from the tumor necrosis factor superfamily and induces apoptosis in transformed cells $(6,7)$. TRAIL can stimulate both proapoptotic and anti-apoptotic pathways, but the mechanism by which a particular pathway is triggered remains less well understood (8). TRAIL binds to TRAIL-R1, R2, R3, and R4 receptors

This study has been presented as a poster at the $29^{\text {th }}$ National Congress of Nephrology, Hypertension, Dialysis and Transplantation, 2012, Antalya, Turkey. Address for Correspondence: Dr. Funda Sarı, Division of Nephrology, Department of Internal Medicine, Antalya Training and Research Hospital, Antalya, Turkey Phone: +90 $5326463442 \quad$ e-mail: fundasari@ymail.com

Received: 8 July 2015 Accepted: 7 May 2016 DOI: 10.5152/balkanmedj.2016.150685

Available at www.balkanmedicaljournal.org 
and a soluble receptor that it is called osteoprotegerin (9-14). TRAIL-R1 and R2 are death-inducing receptors, and TRAILR3, -R4, and osteoprotegerin may act as trap receptors (15).

Although increased levels of apoptosis are observed in human ADPKD (3-5), data regarding sTRAIL levels in patients with chronic renal failure are limited (16). To our knowledge, no previous study evaluated circulating sTRAIL levels in patients with ADPKD. We therefore investigated the circulating sTRAIL in patients with ADPKD and the relationship between serum sTRAIL levels and severity of renal failure in these patients.

\section{MATERIALS AND METHODS}

The study was approved by the local ethics committee and was performed in appropriate with the ethical rules of the Declaration of Helsinki. Inform consent was taken from all patients. A total of 44 patients with ADPKD (22 males, 22 females, mean age $56.7 \pm 12.1$ years) who had been diagnosed by modified Ravine criteria and a positive family history of ADPKD were included in the study, with 18 healthy volunteers as a control group ( 9 male, 9 female, mean age: $57.8 \pm 14.5$ years) were included in this study. The healthy subjects with comparable gender, age and body mass index were enrolled to study as a control group. Subjects with diabetes mellitus, obesity, dyslipidemia, coronary artery disease, cerebrovascular disease, peripheral arterial disease, malignancy, smoking history were excluded from the study.

Glomerular filtration rate (GFR) values were measured by dhronic kidney disease epidemiology collaboration (CKD-EPI) formulation (17). The patients were classified by chronic kidney disease (CKD) stages consequently to the Kidney Disease Outcomes Quality Initiative (KDOQI) guidelines (18).

The human soluble TRAIL/Apo2L ELISA kit (ReproTech; New Jersey, USA) was used for the in-vitro quantitative determination of sTRAIL in serum samples. All the clinical follow-up markers including blood urea nitrogen, serum albumin, creatinine, uric acid, calcium, chloride and C-reactive protein were also evaluated by clinical biochemistry diagnostic laboratory kits.

\section{Statistical analysis}

The results were evaluated statistically using the Statistical Package for the Social Sciences (SPSS Corp.; version 16.0, Chicago, IL, USA). Continuous variables are shown as mean \pm standard deviation; categorical variables are shown as frequency and percentage. Normal distribution was evaluated by Shapiro Wilk's test. According to the presence of normal distribution of the parameters, for the analysis of continuous variables the Mann-Whitney $U$ test and t-test (independent samples t-test) were used. One-way ANOVA and Kruskal Wallis tests were used for comparisons of age and sTRAIL by stage. Pearson and Spearman's rho tests were used for correlation analysis. With $95 \%$ confidence interval, a $p$ value less than 0.05 was considered to be statistically significant.

\section{RESULTS}

Mean age was similar in patients with ADPKD and the control group $(56.7 \pm 12.1$ and $57.8 \pm 14.5$ years, $\mathrm{p}>0.05)$. Mean serum sTRAIL levels were lower in patients with ADPKD than control group $(446.9 \pm 103.1$ and $875.9 \pm 349.6 \mathrm{pg} /$ $\mathrm{mL}, \mathrm{p}<0.001$ ) (Table 1).

In patients with $\mathrm{ADPKD}$, mean hemoglobin level was $12.7 \pm 1.4 \mathrm{~g} / \mathrm{dL}$; serum creatinine level was $4.0 \pm 3.7 \mathrm{mg} / \mathrm{dL}$; serum albumin level was $4.2 \pm 0.9 \mathrm{~g} / \mathrm{dL}$; C-reactive protein level was $1.8 \pm 0.5 \mathrm{mg} / \mathrm{L}$; GFR level was $36.1 \pm 24.0 \mathrm{~mL} / \mathrm{min}$ (Table 1).

There was negative correlation between serum sTRAIL levels and hemoglobin in patients with ADPKD ( $r=-0.348$, $\mathrm{p}=0.02$ ). There was no correlation between serum sTRAIL levels and the other parameters (age, GFR, serum creatinine, serum albumin, C-reactive protein) (Table 2). Serum sTRAIL levels did not differ with stages of renal failure in patients with ADPKD (Table 3).

TABLE 1. Characteristics of patients with ADPKD and HV

\begin{tabular}{lccc}
\hline & $\begin{array}{c}\text { ADPKD } \\
(\mathrm{n}=44)\end{array}$ & $\begin{array}{c}\text { HV } \\
(\mathrm{n}=18)\end{array}$ & $\mathrm{p}$ \\
\hline Age (years) & $56.7 \pm 12.1$ & $57.8 \pm 14.5$ & 0.471 \\
Female, No (\%) & $22(50 \%)$ & $9(50 \%)$ & 0.955 \\
Male, No (\%) & $22(50 \%)$ & $9(50 \%)$ & 0.930 \\
Body Mass Index (kg/m²) & $28.21 \pm 5.34$ & $27.37 \pm 4.31$ & 0.400 \\
Hemoglobin (g/dL) & $12.7 \pm 1.4$ & $13.9 \pm 0.9$ & 0.250 \\
Creatinine (mg/dL) & $4 \pm 3.7$ & $0.77 \pm 0.2$ & $<0.001$ \\
eGFR (ml/min/1.73m²) & $36.1 \pm 24$ & $98.1 \pm 10.7$ & $<0.001$ \\
Calcium (mg/dL) & $8.9 \pm 2.3$ & $9.37 \pm 0.39$ & 0.095 \\
Phosphate (mg/dL) & $4.51 \pm 1.7$ & $4.0 \pm 0.67$ & 0.089 \\
Parathyroid hormone (pg/mL) & $162.3 \pm 268.9$ & $47.7 \pm 12.3$ & $<0.001$ \\
Albumin (g/dL) & $4.2 \pm 0.9$ & $4.6 \pm 0.28$ & 0.150 \\
Serum sTRAIL (pg/mL) & $446.9 \pm 103.1$ & $875.9 \pm 349.6$ & $<0.001$ \\
\hline
\end{tabular}

HV: healthy volunteers; ADPKD: autosomal dominant polycystic kidney disease; eGFR: estimated Glomerular filtration rate; sTRAIL: soluble TNF-related apoptosis inducing ligand 
TABLE 2. Correlation between serum sTRAIL levels, demographics and laboratory parameters in patients with ADPKD

\begin{tabular}{lcc}
\hline & \multicolumn{2}{c}{ Serum sTRAIL $(\mathrm{pg} / \mathrm{mL})$} \\
\cline { 2 - 3 } & $\mathrm{r}$ & $\mathrm{p}$ \\
\hline Age (years) & 0.175 & 0.445 \\
Body Mass Index $\left(\mathrm{kg} / \mathrm{m}^{2}\right)$ & 0.150 & 0.550 \\
Hemoglobin $(\mathrm{g} / \mathrm{dL})$ & -0.348 & 0.02 \\
C-Reactive Protein $(\mathrm{mg} / \mathrm{L})$ & 0.059 & 0.940 \\
Creatinine $(\mathrm{mg} / \mathrm{dL})$ & 0.135 & 0.750 \\
eGFR(ml/min/1.73m $\left.{ }^{2}\right)$ & 0.127 & 0.720 \\
Calcium (mg/dL) & 0.120 & 0.355 \\
Phosphate (mg/dL) & 0.025 & 0.625 \\
Parathyroid hormone (pg/mL) & 0.190 & 0.945 \\
Albumin (g/dL) & 0.155 & 0.150 \\
\hline
\end{tabular}

ADPKD: autosomal dominant polycystic kidney disease; eGFR: estimated Glomerular filtration rate; sTRAIL: soluble TNF-related apoptosis inducing ligand

TABLE 3. Age and sTRAIL in patients with ADPKD

\begin{tabular}{lccccc}
\hline & $\begin{array}{c}\text { Stage II } \\
\mathrm{N}=19\end{array}$ & $\begin{array}{c}\text { Stage III } \\
\mathrm{N}=5\end{array}$ & $\begin{array}{c}\text { Stage IV } \\
\mathrm{N}=4\end{array}$ & $\begin{array}{c}\text { Stage V } \\
\mathrm{N}=16\end{array}$ & $\mathrm{p}$ \\
\hline Age (year) & $56.5 \pm 13.6$ & $60.1 \pm 11.9$ & $57.3 \pm 9.7$ & $54.5 \pm 11.4$ & 0.565 \\
sTRAIL $(\mathrm{pg} / \mathrm{mL})$ & $447.9 \pm 104.6$ & $452.1 \pm 110.5$ & $439.8 \pm 68.6$ & $436.7 \pm 103.5$ & 0.750 \\
\hline
\end{tabular}

HV: healthy volunteers; ADPKD: autosomal dominant polycystic kidney disease; eGFR: estimated Glomerular filtration rate; sTRAIL: soluble TNF-related apoptosis inducing ligand

\section{DISCUSSION}

Autosomal dominant polycystic kidney disease is a genetic disease that presented by the development of many cysts in the kidney and other organs. The certain mechanism involved in the pathogenesis of ADPKD has not been determined. There have been major advances in the study of the pathophysiology of cyst formation and the progression of renal failure in ADPKD (2). One of those potential factors in cyst formation and loss of non-cystic tubules leading to renal failure in ADPKD is apoptosis. Increased levels of apoptosis are observed in human ADPKD (3-5) and experimental models of ADPKD (19-22). Furthermore, apoptosis has been reported in kidneys of humans with ADPKD regardless of renal function (5).

Cell death via apoptosis through the stimulation of specific intracellular pathways is a stimulation response of cells to affected microenvironments $(22,23)$. Lethal cytokines, they are members of the TNF superfamily, stimulate decease receptors on the cell surface with consequent stimulation of caspases, central activators, and effectors of apoptosis (23-25). The apoptotic process is regulated by a host of checks and balances with a many of positive and negative factors (26). The
TNF- $\alpha$ is essential for induction of cytokine cascade which composing immune response. Also, TNF- $\alpha$ participates in immune response, inflammation and wound healing. The role and molecular function of the TRAIL and its receptors' system in the immune system has been extensively studied and various results were presented (8-14,27).

Vascular calcification and endothelial dysfunction are frequent in patients with chronic kidney disease. Accumulating experimental and clinical evidence suggests that TRAIL is associated with atherosclerosis. The circulating TRAIL level is positively associated with endothelial function, and TRAIL deficiency results in accelerated calcification in atherosclerosis (28-30).

Although increased levels of apoptosis are observed in human ADPKD, to our knowledge, no previous study has evaluated circulating sTRAIL levels in patients with ADPKD. In this study, we assessed the serum levels of sTRAIL as a marker of overall apoptotic activity in ADPKD. Serum sTRAIL levels were lower in patients with ADPKD than control group.

Data regarding sTRAIL levels in patients with CKD are limited (16). Liabeuf et al. (16) reported that patients undergoing hemodialysis had significantly lower serum sTRAIL levels when compared with patients with earlier stages of CKD, and lower serum STRAIL levels had been related to increased mortality in CKD patients. Furthermore, they found no correlation between serum sTRAIL and estimated GFR. Serum sTRAIL levels were not different between stages of CKD. This different result in patients with undergoing hemodialysis may be related etiological factor of chronic renal failure and blood sample collection time (predialysis or after dialysis period). Our study population was homogenous etiology (ADPKD) of CKD and sample for blood collection in pre-dialythic period. In addition, we did not find any correlation between sTRAIL and the estimated GFR, similarly their study.

Clinical presentation of ADPKD differs from the other CKD causes with less frequent occurrence of anemia due to higher serum erythropoietin levels. Recent studies indicate that in ADPKD patients, proximal tubuli is the main site for erythropoietin production and erythropoietin is significantly enriched in cysts of proximal tubular origin $(31,32)$. Both in vitro and in vivo studies have clearly documented that TRAIL shows regulatory functions in hematopoiesis under normal and pathological conditions (33-36). Choi reported that negative correlation between STRAIL and hemoglobin levels in healthy adults (34). We also found a negative correlation between sTRAIL and hemoglobin levels in patients with ADPKD.

Our study has several limitations. First, the sample size of our cohort (especially for each stage of CKD) was relatively small. Second, we relied on single measurement serum sTRAIL levels instead of serial monitoring. Third, we did 
not analyze the cellular (for example cystic lesion) levels of sTRAIL. Therefore, new studies that have more sample sizes are necessary for this purpose. In conclusion, our results show that ADPKD patients have depressed sTRAIL levels as an indicator of apoptosis which was not related to stage of CKD.

Ethics Committee Approval: Ethics committee approval was received fort his study from the ethics committee of Ministry of Health.

Informed Consent: Written informed consent was obtained from patients who participated in this study.

Peer-review: Externally peer-reviewed.

Author contributions: Concept - F.S., M.S. ; Design - F.S., A.D.Y.; Supervision - F. S.; Resource - F.S., G.E.G., M.S.; Materials - F.S., M.S., S.G.; Data Collection and/or Processing - F.S., G.E.G., A.B., S.G.; Analysis and/or Interpretation - F.S., A.B., S.G.; Literature Search - F.S.; Writing - F.S.; Critical Reviews - F.S., A.D.Y., R.Ç.

Conflict of Interest: No conflict of interest was declared by the authors.

Financial Disclosure: The authors declared that this study has received no financial support.

\section{REFERENCES}

1. Gabow PA. Autosomal dominant polycystic kidney disease. $N$ Engl J Med 1993;329:332-42. [CrossRef]

2. Gattone VH 2nd, Calvet JP, Cowley BD Jr, Evan AP, Shaver TS, Helmstader K, et al. Autosomal recessive polycystic kidney disease in a murine model. A gross and microscopic description. Lab Invest 1988;59:231-8.

3. Zhou XJ, Kukes G. Pathogenesis of autosomal dominant polycystic kidney disease: role of apoptosis. Diagn Mol Pathol 1998;7:65-8. [CrossRef]

4. Lanoix J, D'Agati V, Szabolcs M, Trudel M. Dysregulation of cellular proliferation and apoptosis mediates human autosomal dominant polycystic kidney disease (ADPKD). Oncogene 1996;13:1153-60.

5. Woo D. Apoptosis and loss of renal tissue in polycystic kidney diseases. N Engl J Med 1995;333:18-25. [CrossRef]

6. Wiley SR, Schooley K, Smolak PJ, Din WS, Huang CP, Nicholl $\mathrm{JK}$, et al. Identification and characterization of a new member of the TNF family that induces apoptosis. Immunity 1995;3:67382. [CrossRef]

7. Pitti RM, Marsters SA, Ruppert S, Donahue CJ, Moore A, Ashkenazi A. Induction of apoptosis by Apo-2 ligand, a new member of the tumor necrosis factor cytokine family. $J$ Biol Chem 1996;271:12687-90. [CrossRef]
8. Corallini F, Rimondi E, Secchiero P. TRAIL and osteoprotegerin: a role in endothelial physiopathology? Front Biosci 2008;13:135-47. [CrossRef]

9. Pan G, O'Rourke K, Chinnaiyan AM, Gentz R, Ebner R, Ni $\mathrm{J}$, et al. The receptor for the cytotoxic ligand TRAIL. Science 1997;276:111-3. [CrossRef]

10. Walczak H, Degli-Esposti MA, Johnson RS, Smolak PJ, Waugh JY, Boiani N, et al. TRAIL-R2: a novel apoptosis-mediating receptor for TRAIL. EMBO J 1997;16:5386-97. [CrossRef]

11. Pan G, Ni J, Wei YF, Yu G, Gentz R, Dixit VM. An antagonist decoy receptor and a death domain-containing receptor for TRAIL. Science 1997;277:815-8. [CrossRef]

12. Sheridan JP, Marsters SA, Pitti RM, Gurney A, Skubatch M, Baldwin D, et al. Control of TRAIL induced apoptosis by a family of signaling and decoy receptors. Science 1997;277:818-21. [CrossRef]

13. Degli-Esposti MA, Dougall WC, Smolak PJ, Waugh JY, Smith CA, Goodwin RG. The novel receptor TRAIL-R4 induces NFkappaB and protects against TRAIL-mediated apoptosis, yet retains an incomplete death domain. Immunity 1997;7:813-20. [CrossRef]

14. Shipman CM, Croucher PI. Osteoprotegerin is a soluble decoy receptor for tumor necrosis factor-related apoptosis-inducing ligand/Apo2 ligand and can function as a paracrine survival factor for human myeloma cells. Cancer Res 2003;63:912-6.

15. Smyth MJ, Takeda K, Hayakawa Y, Peschon JJ, van den Brink MR, Yagita H. Nature's TRAIL-on a path to cancer immunotherapy. Immunity 2003;18:1-6. [CrossRef]

16. Liabeuf S, Barreto DV, Barreto FC, Chasseraud M, Brazier M, Choukroun $\mathrm{G}$, et al. The circulating soluble TRAIL is a negative marker for inflammation inversely associated with the mortality risk in chronic kidney disease patients. Nephrol Dial Transplant 2010;25:2596-602. [CrossRef]

17. Levey AS, Stevens LA, Schmid CH, Zhang YL, Castro AF 3rd, Feldman HI, et al A New Equation to Estimate Glomerular Filtration Rate. Ann Intern Med 2009;150:604-12. [CrossRef]

18. K/DOQI clinical practice guidelines for chronic kidney disease: evaluation, classification, and stratification. National Kidney Foundation. Am J Kidney Dis 2002;39(2 Suppl 1):S1-266.

19. Murcia NS, Sweeney WE Jr, Avner ED. New insights into the molecular pathophysiology of polycystic kidney disease. Kidney Int 1999;55:1187-97. [CrossRef]

20. Trudel M, Barisoni L, Lanoix J, D’Agati V. Polycystic kidney disease in SBM transgenic mice: role of c-myc in disease induction and progression. Am J Pathol 1998;152:219-29.

21. Winyard PJ, Nauta J, Lirenman DS, Hardman P, Sams VR, Risdon RA, et al. Deregulation of cell survival in cystic and dysplastic renal development. Kidney Int 1996;49:135-46. [CrossRef]

22. Ecder T, Melnikov VY, Stanley M, Korular D, Lucia MS, Schrier RW, et al. Caspases, Bcl-2 proteins and apoptosis in autosomaldominant polycystic kidney disease. Kidney Int 2002;61:122030. [CrossRef]

23. Agostini M, Tucci P, Melino G. Cell death pathology: perspective for human diseases. Biochem Biophys Res Commun 2011;414:451-5. [CrossRef] 
24. Lorz C, Benito-Martin A, Justo P, Sanz AB, Sanchez-Ni-o MD, Santamaria B, et al. Modulation of renal tubular cell survival: where is the evidence? Curr Med Chem 2006;13:449-54. [CrossRef]

25. Sanchez-Ni-o MD, Benito-Martin A, Gonçalves S, Sanz AB, Ucero AC, Izquierdo MC, et al. TNF superfamily: a growing saga of kidney injury modulators. Mediators Inflamm 2010;2010. pii: 182958.

26. Sanchez-Ni-o MD, Benito-Martin A, Ortiz A. New paradigms in cell death in human diabetic nephropathy. Kidney Int 2010;78:737-44. [CrossRef]

27. Collison A, Foster PS, Mattes J. Emerging role of tumour necrosis factor-related apoptosis-inducing ligand (TRAIL) as a key regulator of inflammatory responses. Clin Exp Pharmacol Physiol 2009;36:1049-53. [CrossRef]

28. Di Bartolo BA, Cartland SP, Harith HH, Bobryshev YV, Schoppet M, Kavurma MM. TRAIL-deficiency accelerates vascular calcification in atherosclerosis via modulation of RANKL. PLoS One 2013;8:e74211. [CrossRef]

29. Secchiero P, Gonelli A, Carnevale A, Milani D, Pandolfi A, Zella D, et al. TRAIL promotes the survival and proliferation of primary human vascular endothelial cells by activating the Akt and Erk pathway. Circulation 2003;107:2250-6. [CrossRef]
30. Xiang G, Yue L, Zhang J, Xiang L, Dong J. The relationship between circulating TRAIL and endothelial dysfunction in subclinical hypothyroidism. Endocrine 2015;49:184-90. [CrossRef]

31. de Almeida EAF, Alho I, Marques F, Thiran C, Bicho MP, Prata M. Haemoglobin and erythropoietin levels in polycystic kidney disease. Nephrol Dial Transplant 200;23:412-3.

32. Eckardt KU, Möllmann M, Neumann R, Brunkhorst R, Burger HU, Lonnemann G, et al. Erythropoietin in polycystic kidneys. J Clin Invest 1989;84:1160-6. [CrossRef]

33. Zauli G, Secchiero P. The role of the TRAIL/TRAIL receptors system in hematopoiesis and endothelial cell biology. Cytokine Growth Factor Rev 2006; 17:245-57. [CrossRef]

34. Choi JW. Relationships between tumor necrosis factor (TNF)related apoptosis-inducing ligand (TRAIL) and hematopoietic activity in healthy adults. Ann Hematol 2005;84:728-33. [CrossRef]

35. Zamai L, Secchiero P, Pierpaoli S, Bassini A, Papa S, Alnemri ES, et al. TNF-related apoptosis-inducing ligand (TRAIL) as a negative regulator of normal human erythropoiesis. Blood 2000;95:3716-24.

36. Silvestris F, Cafforio P, Tucci M, Dammacco F. Negative regulation of erythroblast maturation by Fas-L $(+) / \operatorname{TRAIL}(+)$ highly malignant plasma cells: a major pathogenetic mechanism of anemia in multiple myeloma. Blood 2002;99:1305-13. 